\title{
Determinants of abundance and habitat association of mammals in Barandabhar Corridor Forest, Chitwan, Nepal
}

\author{
Jagan Nath Adhikari ${ }^{1,2 \S}$, Bishnu Prasad Bhattarai ${ }^{18^{*}}$, Tej Bahadur Thapa ${ }^{1}$ \\ ${ }^{1}$ Central Department of Zoology, Tribhuvan University, Kirtipur, Kathmandu, Nepal \\ ${ }^{2}$ Department of Zoology, Birendra Multiple Campus, Tribhuvan University, Chitwan, Nepal \\ ${ }^{\S}$ These authors contributed equally to this work.
}

\begin{abstract}
AdHiKARI, J.N., BhatTARAI, B.P., ThaPA, T.B., 2021. Determinants of abundance and habitat association of mammals in Barandabhar Corridor Forest, Chitwan, Nepal. Folia Oecologica, 48 (1): 100-109.

Barandabhar Corridor Forest (BCF), the biologically functional corridor, is surrounded by the large human settlements that exploit the corridor where large mammals such as tigers, leopards and their prey such as ungulates, primates, and rhinoceros occur. This study aimed to evaluate major determinants that affect the distribution of large mammals in BCF, Chitwan, Nepal that connects the biologically significant Chitwan National Park with the Mahabharat range. The status and distribution of large mammals along the habitat and disturbance gradients were determined by using 29 line transects (mean length $=4.59 \pm 0.38 \mathrm{~km}$ ) that covered a linear distance of $133.13 \mathrm{~km}$. The chital were the most abundant mammals (density per $\mathrm{km}^{2}(\mathrm{D})=8.9095$ \pm 1.4570 and encounter rate per $\mathrm{km}(\mathrm{ER})=1.49)$ followed by rhesus monkey $(\mathrm{D}=38.896 \pm 16.013, \mathrm{ER}=$ $0.28)$, wild boar $(\mathrm{D}=14.814 \pm 3.57, \mathrm{ER}=0.62)$, northern red muntjac $(\mathrm{D}=9.6566 \pm 2.9514, \mathrm{ER}=0.62)$ and sambar $(\mathrm{D}=5.392 \pm 2.319, \mathrm{ER}=0.38)$. Similarly, the sign encounter rate of tiger and leopard was 0.435 and 0.503 respectively. Habitat types, human disturbances, and coverage of invasive and alien plant species (IAPs) played a key role in the distribution of large mammals. The occurrence of mammals was low nearer to the settlements and roads and coverage of IAPs and more nearer to the water resources. However, degradation of foraging grounds such as grasslands by succession and invasion of alien plant species added more threats to the survival of large mammals. Therefore, such a situation can be improved through the scientific management of forests and grasslands.
\end{abstract}

\section{Keywords}

disturbance, habitat heterogeneity, leopard, tiger, ungulates

\section{Introduction}

The 'habitat heterogeneity hypothesis' (HHH), is one of the cornerstones of ecology, and often discussed in macroecology and biogeography. Maintaining habitat heterogeneity has been proposed as a mean of conserving species richness in habitats threatened by the human activities (MACARTHUR and MACARTHUR, 1961). In an ecosystem, when many habitats can support the large population of the species, the diversity of the species should be high because the heterogonous habitats can hold different habitat specialist animals (Tews et al., 2004). There is well-founded and widespread concern about the impact of habitat loss and fragmentation on biodiversity. Some area-sensitive species which are survived in the small habitat patches become extinct when habitat loss is going continuously (HADDAD et al., 2015; BARTLETT et al., 2016). 
The interrelationship between animals and their natural habitats in human-dominated landscapes is one of the main issues in wildlife conservation as animals and human ecology are closely related (SCHALLER, 1967). The human-wildlife conflict is still the main problem for the conservation of biodiversity in and outside the protected area in the developing countries like Nepal (RAVENELLE and Nyhus, 2017; Acharya, 2018; LamichHane et al., 2019b). The habitat types, topographic features, disturbance gradients, presence of the water resources, and other features of the environment determine the survival of the animals and their breeding success in such areas (ERB et al., 2012; BhatTARAI and KindLMANN, 2013; OberosLer et al., 2020). This is especially true for endangered mammals (LAIDLAW, 2000; SAISAMORN et al., 2019).

The species richness of the mammals is affected more by the spatial and habitat heterogeneity than the size of the habitats (WANG et al., 2006; BÁLDI, 2008). Hence, promoting high spatial heterogeneity is a major component of animal conservation (Tews et al., 2004; SAISAMORN et al., 2019). Global extinction of species, driven by anthropogenic factors, is occurring at an unprecedented rate (BARTLETT et al., 2016).

This study mainly concentrates on two major predators tiger and leopard and ungulates (sambar Rusa unicolor (Kerr, 1792), chital Axis axis (Erxleben, 1777), northern red muntjac Muntiacus vaginalis (Boddaert, 1785), wild pig Sus scrofa Linnaeus, 1758, hog deer Axis porcinus (Zimmermann, 1780)) and large herbivore greater onehorned rhino Rhinoceros unicornis Linnaeus, 1758, two primates rhesus monkey Macaca mulatta (Zimmermann, 1780) and Terai grey langur Semnopithecus hector (Pocock, 1928) and their habitat and disturbance components in Barandabhar Corridor Forest (BCF). Knowledge of species distributions along with the habitat types and disturbance gradients could help to protect the mammals in that area (RoDrigues et al., 2006). Most of the researches in BCF focussed on the population status and conservation threats of wild ungulates (BHATTARAI and Basnet, 2004; Bhattarai and Kindlmann, 2018), and large carnivores (THAPA, 2011; BHATTARAI and Kindlmann, 2012a; LAMichHane et al., 2019a). There are even research gaps on the distribution of large mammals along the habitat and disturbance gradients. Hence this study explored the (1) abundance of the large mammals in $\mathrm{BCF},(2)$ major factors (anthropogenic and natural) that play the role in the distribution of large mammals in BCF.

\section{Methods}

\section{Study area}

The Barandabhar Corridor Forest (BCF) is a functional vertical (South-North) corridor that connects two different

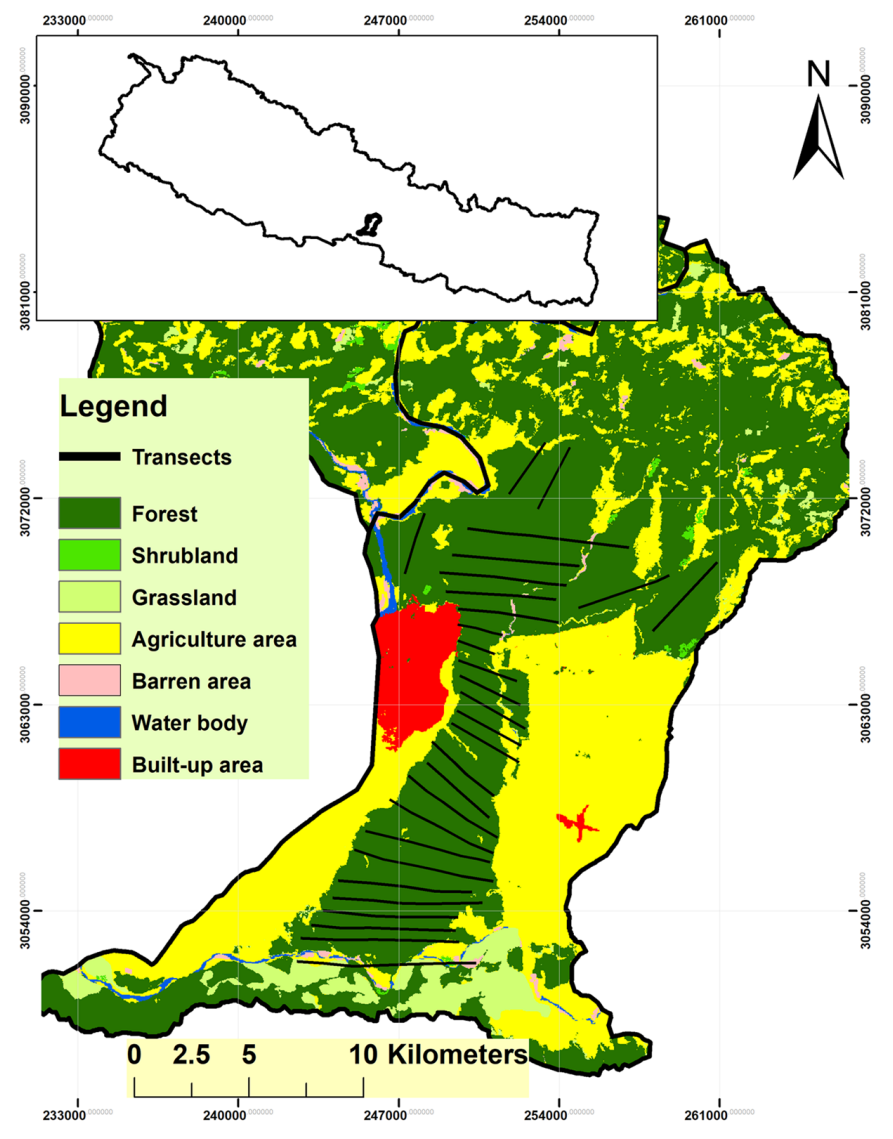

Fig. 1. Study area along with transects layout in BCF (ICIMOD, 2013). 
ecosystems with significant altitudinal variations (Fig. 1). This functional bio-corridor connects especially the lowland Chitwan National Park and the highland Mahabharat range in Nepal which is located between $27^{\circ} 34^{\prime}$ to $27^{\circ} 40^{\prime} \mathrm{N}$ latitude and $84^{\circ} 21^{\prime}$ to $84^{\circ} 28^{\prime}$ 'E longitude, covering an area $96.02 \mathrm{~km}^{2}$. The forest is regarded as the only remaining wildlife corridor that links the lowland to mid-hill ecosystems in the central part of the country (Bhattarai and Kindlmann, 2012b; AdhiKari et al., 2019b). The east-west highway (Asian Highway 2 (AH2)) bisects this corridor. The southern part of this corridor falls in the buffer zone of Chitwan National Park and is managed by the park whereas the northern part is the protected forest and is managed by Division Forest Office, Chitwan. The human pressure is relatively higher in the northern part as this corridor is surrounded by heavily populated urban settlements named Ratnanagar Municipality on the East, Kalika on North-east, and Bharatpur Metropolitan City in the West.

$\mathrm{BCF}$ has a humid and subtropical monsoon climate. The mean monthly temperature varies from $15^{\circ} \mathrm{C}$ in January to $29^{\circ} \mathrm{C}$ in June and annual rainfall ranges from 1,800 to 2,200 mm/annum (THAPA, 2011). BCF is dominated by sal (Shorea robusta) forest, partly by mixed forest, riverine forest, and grasslands. This area is also rich in wetland habitats such as Beeshazari lake (a Ramsar site), Kumal lake, Rhino lake, and Batulopokhari lake that makes the vegetation denser and wetter than previous. Sal forest is mainly associated with Terminalia forest. Riverine type of vegetation mainly occurs in the southern and northern part of BCF. The dense riverine forest is found nearby the water courses and is dominated mainly by Bhellar Trewia nudiflora along the Rapti, Budi Rapti and Khageri rivers. Short grasslands are distributed as patches mainly inside the sal forest ranging from 0.02 to $0.3 \mathrm{~km}^{2}$ throughout $\mathrm{BCF}$ (Fig.1).

\section{Data collection}

The abundance of the prey species of tiger and leopard (ungulates and monkeys) was estimated by using the direct observation method along transects. The size and the length of the transects were different according to the habitat type and size of the forest patches (SILVEIRA et al., 2003). The transects were selected based on the dimension of the forest. The length of the transect varied depending on the width of the forest. The linear distance between the two transects was $500 \mathrm{~m}$. The locations of transects were designed with the accessibility for walking. We walked 29 transects and covered the linear distance of $133.13 \mathrm{~km}$ (average length $=4.59 \mathrm{~km}, \mathrm{SE}=0.308$, range $=2$ to $7.8 \mathrm{~km}$ ) (Fig. 1). The data were collected in the morning (6 to $10 \mathrm{AM}$ ) and evening ( 3 to $6 \mathrm{PM}$ ) time when the mobility of the mammals was maximum. We recorded all the mammals along with age, sex, and herd composition. The data were collected two times from January to July 2018 and 2019 using four observers at a time for four directions to minimize the observation error. We also recorded sighting angle and distance by using the laser rangefinder (Bushnell, 7X with $500 \mathrm{~m}$ range). The age and sex composition of the mammals were identified by the direct observation method using binoculars (Nikon, $20 \times 50$ ).

The signs left by the animals such as pugmarks/ footprint, dung/ dropping/scat, and other signs (scrap, scent marks, etc.) are a reliable indicator of animal presence and have frequently been used for estimating abundance (Bhattarai and Kindlanann, 2012a). The signs left by the large mammals (mainly tiger and leopard) as scat, scratch, scrap marks, pugmarks, were observed at regular intervals of $100 \mathrm{~m}$ distance, by developing the quadrates of $10 \times 10$ $\mathrm{m}^{2}$ to determine the presence or absence of tiger or leopard.

The dominant habitat types, coverage of IAPs, and human disturbance indicators were recorded at the interval of $100 \mathrm{~m}$ along a transect within the quadrates of $10 \times 10$ $\mathrm{m}^{2}$. The habitat of BCF was classified into four categories such as sal forest, riverine forest, grassland, and mixed forest (Table 1).

In each sampling point, we recorded the following information.

1. Species variables:

a. Six species of ungulates: chital $(\mathrm{CH})$, sambar (SD), northern red muntjac (MD), hog deer (HD), wild pig (WP), greater one-horned rhino $(\mathrm{RH})$, and two primate species: Terai grey langur (Cla), rhesus monkey (RH) seen b. Signs of the presence of two species of predators: tiger (Tig) and leopard (LP).

2. Environmental variables:

2.1. Habitat variables

a. Types of habitats such as sal forest (SF), riverine forest (RF), grassland (GL), and mixed forest (MF) (Table 1)

b. Forest cover: dense (Den) - greater than 50\% canopy cover or moderately dense (Mden) - 20-50\% canopy cover or open (Opn) - less than $20 \%$ canopy cover, and c. Distance to the nearest waterhole (Euclidean distance measured from sampling point to the nearest waterhole)

2.2. Disturbance variables (anthropogenic)

a. People's presence is based on the numbers of lopped and logged trees and sites used for harvesting grass

b. The number of tourists/visitors present inside the BCF during the survey period

c. Number of vehicle present inside the BCF during the survey period

d. Livestock presence is based on the number of dung and head of livestock.

Habitat disturbance status was calculated by using all the human disturbance variables as listed above. The human presence indicators (numbers of lopped trees, logged trees, sites used for harvesting grass) and livestock presence (number of individuals and dungs of livestock), number of tourists present, number of fishermen variables were combined and scored on an ordinal scale of 1 to 5 based on the total number of signs of disturbance as 1, 2, 3, 4 or 5 indicating a very low (VLW), low disturbance (LW), moderate (MD), high (HD) or very high (VHD) level of habitat disturbance status respectively. 
Table 1. Description of different habitats recorded during field study

\begin{tabular}{|c|c|}
\hline Habitat & Description \\
\hline Sal forest (SF) & $\begin{array}{l}\text { The main dominant species is Shorea robusta C. F. Gaertn. and the associate species is } \\
\text { Terminalia alata Heyne ex Roth. }\end{array}$ \\
\hline Riverine forest (RF) & $\begin{array}{l}\text { Forest present along the rivers and their catchment area. The major tree species are Trewia } \\
\text { nudiflora L., Bombax ceiba L.and Dalbergia sissoo DC. }\end{array}$ \\
\hline Mixed forest (MF) & $\begin{array}{c}\text { Forest of Shorea robusta C. F. Gaertn. Dillenia pentagyna Roxb., Shorea robusta Roth, } \\
\text { Careya arborea Roxb., Xeromphis uliginosa (Retz.), Terminalia alata Heyne ex Roth, } \\
\text { Lagerstroemia parviflora Roxb. }\end{array}$ \\
\hline Grassland (Gl) & $\begin{array}{l}\text { The patches of the grassland including Imperata spp, Narenga porphyrocoma, Saccharum } \\
\text { bengalense and Saccharum spontaneum, present inside the large patch of forest and in the } \\
\text { flood plain of Rapti, Budi Rapti and Khageri rivers }\end{array}$ \\
\hline
\end{tabular}

\section{Data analysis}

Conventional distance sampling (CDS) (in DISTANCE 7.2 Release 1) method was used to estimate the density of animals (D) per square kilometre, density of clusters (DS) per square kilometre, the expected value of cluster size $(\mathrm{E}(\mathrm{S})$ ), and encounter rate (ER) per kilometre. (THOMAS et al., 2010). The main aim to use DISTANCE was to compare the abundances of the prey species of tiger and leopard in BCF. The estimated individuals and clusters or groups of the prey species of tiger and leopard were calculated by running a half-normal model (BUCKLAND et al., 2015). We also calculated the standard errors and Monte Carlo confidence intervals of densities and the criterion of a minimum Akaike's Information Criterion (AIC), chisquare goodness of fit test was used to judge the model. The hog deer, rhinoceros, and common langur were removed from this analysis as we have below 30 observations. The encounter rate of these animals was manually calculated by dividing the total number of individual recorded by total length of transects in kilometre. The signs encounter rate of the predators (tiger and leopard) was calculated manually by dividing the total number of signs encounter by the total length of the transects.

We selected Canonical Correspondence Analysis (CCA) to measure the associations of the species with habitat and disturbance variables using Program CANOCO (CANOCO v. 4.56) (TER BrAAK et al., 2009). In addition, the data is presenting in the form of a biplot (MACFADEN and CAPEN, 2002), CCA helps to compare a complex relationship between species and the environment. For all analyses, a Monte-Carlo permutation test (using 499 unrestricted permutations) was used to identify the environmental variables that are significantly associated with the variation in the distribution of species.

\section{Results}

\section{Abundance of mammals}

The most abundant prey species of tiger and leopard was the chital $(n=2,301)$ and greater one horned rhinoceros was the least abundant mammal $(n=16)$ in BCF. The minimum AIC was obtained for the half-normal model for chital, sambar, northern red muntjac, wild pig and rhesus monkey. The sighting of hog deer, greater onehorned rhino and Terai grey langur was very low (below 30 observations). We recorded 20 individuals of hog deer divided into 7 different groups $(E R=0.150)$ from the transect which was located near the flood plain of Rapti River. We recorded a total of 16 individuals of rhinoceros from 12 observations $(E R=0.12)$ from the transects of different habitats. Likewise, a total of 15 groups of Terai grey langur with 231 individuals $(E R=1.73)$ were recorded from BCF. The chital was the most abundant in terms of the estimated density of animals $(\mathrm{D}=83.855 \pm 19.135)$ and clusters (Ds $=8.9095 \pm 1.4570)$ per square kilometre followed by rhesus monkey $(\mathrm{D}=38.896 \pm 16.013$, $\mathrm{Ds}=$ $2.4767 \pm 0.998)$, wild pig $(\mathrm{D}=14.814 \pm 3.57$, $\mathrm{Ds}=4.87$ $\pm 1.104)$, northern red muntjac $(\mathrm{D}=9.6566 \pm 2.9514$, Ds $=6.6975 \pm 1.397)$ and sambar $(\mathrm{D}=5.392 \pm 2.319$, Ds $=$ $2.933 \pm 1.243)$ (Table 2). The encounter rate of chital was more $(E R=1.49)$ followed by northern red muntjac (ER $=0.624)$, wild pig $(E R=0.623)$, sambar $(E R=0.384)$ and rhesus $(\mathrm{ER}=0.28)($ Table 2$)$.

Tiger and leopard are the large predators in BCF (Fig. 2 ). The estimated sign encounter rate of tiger and leopard per kilometer was 0.435 and 0.503 respectively.

\section{Distribution of mammals across different habitats}

The distribution and abundances of the large mammals depend upon the types and quality of the habitats. There were variations on distribution of large mammals in different seasons of the year. The contribution of explanatory variables for the distribution of the large mammals were analysed by canonical correspondence analysis (CCA). The CCA ordination biplot diagram of different types of mammals present and habitat types indicate that the abundance of hog deer, chital, wild pig, rhinoceros was closely associated with open area grasslands of Rapti and Budi Rapti flood plains and grass patches scattered inside forest types. Chital was the most gregarious species and was highly associated with open areas, i.e. grasslands while the smallest ungulates of 


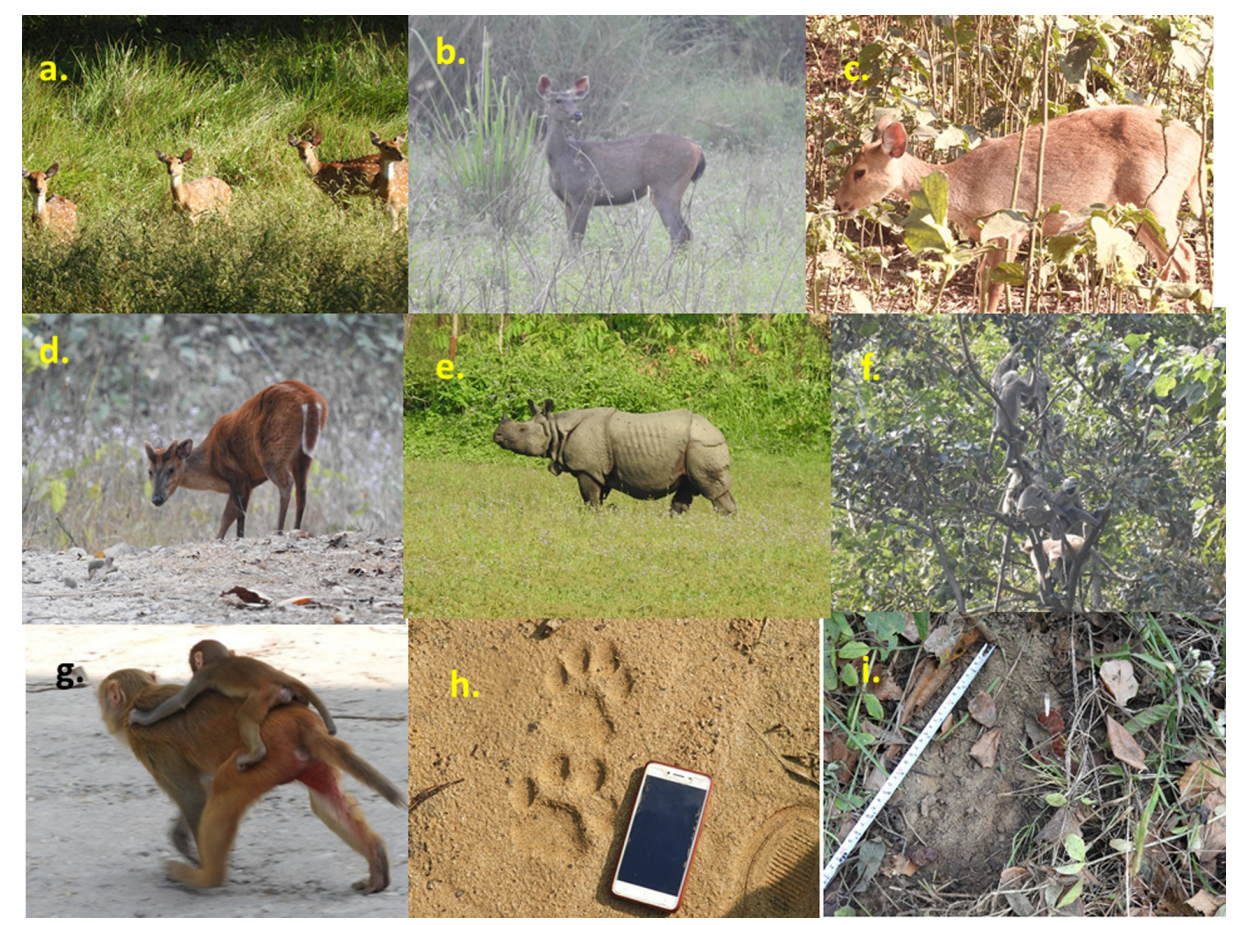

Fig. 2. Large mammals and their sign recorded during field study a. Chital (Axis axis), b. Sambar deer (Rusa unicolor), c. Hog deer (Axis porcinus), d. Northern red muntjac (Muntiacus vaginalis), e. Greater one-horned rhino (Rhinoceros unicornis), f. A troop of Terai grey langur (Semnopithecus hector), g. Mother of rhesus monkey (Macaca mulatta) with her baby, h. Pugmark of tiger (Pathera tigiris), i. Scrap mark of leopard (Panthera pardus). Photo by Jagan Nath Adhikari.

Table 2. Estimated densities of prey species of tiger and leopard in Barandabhar Corridor Forest, Chitwan, based on observing them from distance

\begin{tabular}{|c|c|c|c|c|c|}
\hline Parameter & Chital & Sambar & Muntajc & Wild boar & Rhesus monkey \\
\hline Model & $\mathrm{HN}$ & $\mathrm{HN}$ & $\mathrm{HN}$ & $\mathrm{HN}$ & $\mathrm{HN}$ \\
\hline Cosines & 2,3 & 2,3 & 2 & 2 & 2 \\
\hline AIC & $1,934.5$ & 445.54 & 847.64 & 965.93 & 282.58 \\
\hline $\mathrm{Ni}$ & 2,301 & 99 & 147 & 425 & 532 \\
\hline $\mathrm{Ng}$ & 219 & 50 & 101 & 108 & 32 \\
\hline $\mathrm{Ds} \pm \mathrm{SE}$ & $8.709 \pm 1.957$ & $2.933 \pm 1.243$ & $6.698 \pm 1.397$ & $4.87 \pm 1.104$ & $2.477 \pm 0.998$ \\
\hline $95 \% \mathrm{CI}(\mathrm{Ds})$ & 13.499 & 6.609 & 10.077 & 7.58 & 5.435 \\
\hline $\mathrm{D} \pm \mathrm{SE}$ & $83.855 \pm 19.135$ & $5.392 \pm 2.319$ & $9.657 \pm 2.951$ & $14.814 \pm 3.57$ & $38.896 \pm 16.013$ \\
\hline $95 \% \mathrm{Cl}(\mathrm{D})$ & 130.81 & 12.274 & 14.632 & 23.69 & 86.487 \\
\hline $\mathrm{ES} \pm \mathrm{SE}$ & $9.628 \pm 0.382$ & $1.838 \pm 0.134$ & $1.442 \pm 0.058$ & $3.040 \pm 0.251$ & $15.705 \pm 1.295$ \\
\hline $95 \% \mathrm{Cl}(\mathrm{ES})$ & 10.412 & 2.128 & 1.561 & 3.58 & 18.581 \\
\hline Mean cluster size & $10.507 \pm 0.458$ & $1.98 \pm 0.149$ & $1.455 \pm 0.034$ & $3.935 \pm 0.364$ & $16.625 \pm 1.624$ \\
\hline $\begin{array}{c}\text { Component of } \\
\text { percentage of } \\
\text { variances of ER }\end{array}$ & 38.1 & 15.9 & 32.5 & 23.2 & 11.9 \\
\hline ER & 1.49 & 0.384 & 0.624 & 0.623 & 0.28 \\
\hline Chi_value & 45.159 & 18.087 & 20.076 & 33.128 & 13.114 \\
\hline GOF-p & 0.0001 & 0.001 & 0.028 & 0.0005 & 0.004 \\
\hline
\end{tabular}

$\mathrm{HN}$, half normal; AIC, Akaike's information criterion values; Ni, number of individuals; Ng, number of groups; Ds, density of estimate of density of clusters; SE, standard error; $95 \% \mathrm{CI}(\mathrm{Ds}), 95 \%$ confidence interval of Ds; D, estimate of density of animals; $95 \% \mathrm{Cl}(\mathrm{D}), 95 \%$ confidence interval of D; ES, estimate of expected value of cluster size; $95 \% \mathrm{Cl}(\mathrm{ES}), 95 \%$ confidence interval of ES; ER, encounter rate; GOF-p, P values of chi-square goodness of fit. 
Nepal, northern red muntjac showed a great association with a riverine forest. The sambar deer, the largest deer, were recorded in the dense forest of sal and riverine. The abundance of primate - Terai grey langur was high in the dense riverine and sal forest (Fig. 3). The signs of tiger and leopard were mostly recorded in the grasslands and grass patches scattered in the sal and mixed forest.

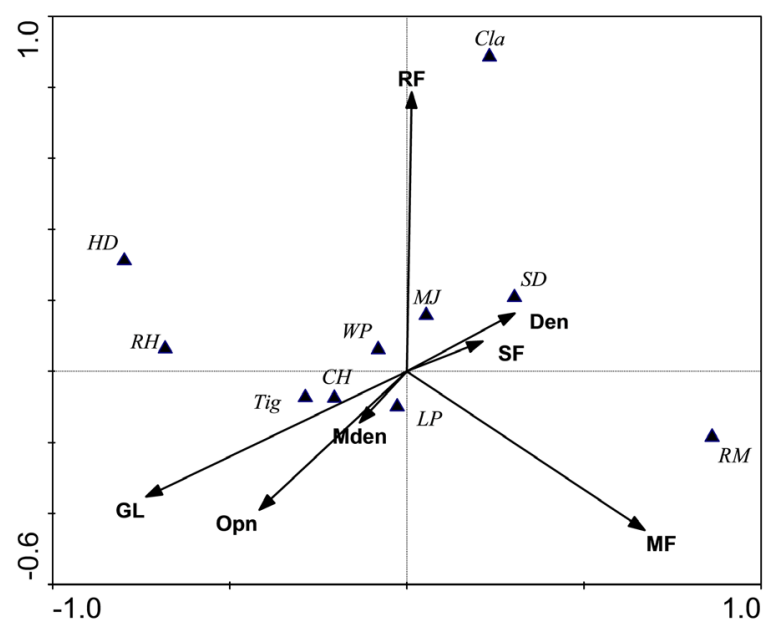

Fig. 3. CCA ordination diagram (biplot) showing species response to different habitats. Monte-Carlo permutation test of significance of all canonical axes: Trace $=0.238, \mathrm{~F}=$ $2.98, \mathrm{p}=0.002$ (with 499 permutations). First two axes are displayed. The first axis accounts for $58.3 \%$ and the second axis $24.3 \%$ of the variability.

\section{Distribution of mammals in disturbance gradients}

The results of CCA showed a close association of rhesus monkey with very highly disturbed areas and the common langur showed a close relation with moderately disturbed areas. Rhinoceros clearly showed a close relation with low disturbed areas. Likewise, hog deer, sambar deer, chital and muntjac showed significantly close association with very low, low, and moderately disturbed areas but wild pigs showed more close association with moderately disturbed and low disturbed areas. The presence signs of tiger showed that they were closely associated with ungulate abundant areas with moderately and low disturbed areas. However, leopard was present in low disturbed areas (Fig. 4). Human disturbances arise while local people visit nearby forest areas for the collection of forest products such as thatch grass, livestock fodder, medicinal plants, and firewood. Besides, livestock grazing and tourist pressure can also cause negative impacts on wildlife. Such disturbance indicators can cause direct or indirect effects on the distribution of wildlife including the large mammals.

The presence of water resources and coverage of the natural habitat with invasive and alien species (IAPs) are the major natural drivers of animal distribution. Distance from the road and village or settlements are also the

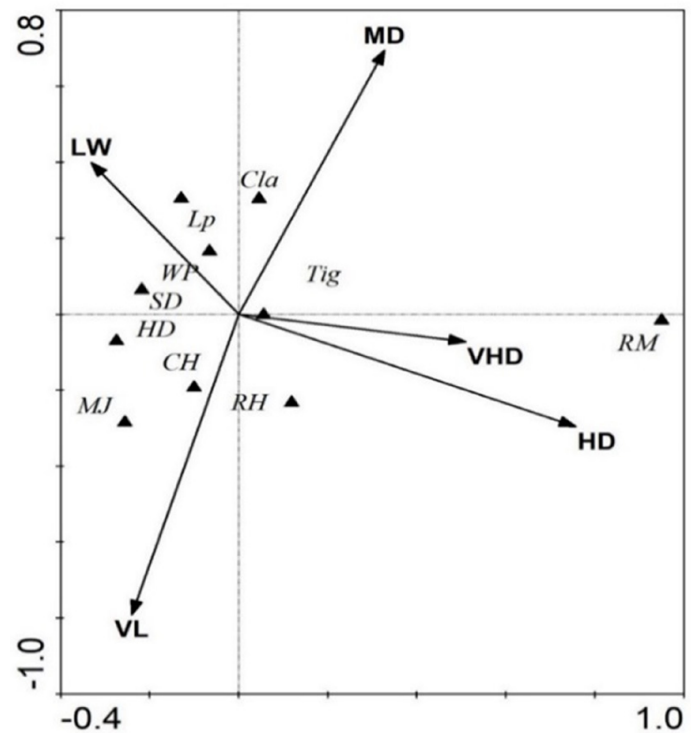

Fig. 4. CCA ordination diagram (biplot) showing species response to different habitat disturbance status. CCA ordination diagram (biplot) showing relationship abundances of the large mammals with different levels of habitat disturbance status (HDS: very high disturbance $=$ VHD; high disturbance $=\mathrm{HD}$; moderately disturbance $=\mathrm{MD}$; low $=\mathrm{LW}$; very low $=\mathrm{VL})$. Monte-Carlo permutation test of significance of all canonical axes: Trace $=0.092, \mathrm{~F}=8.378, \mathrm{p}=0.002$ (with 499 permutations). First two axes are displayed. The first axis accounts for $84.6 \%$ and the second axis $10.2 \%$ of the variability.

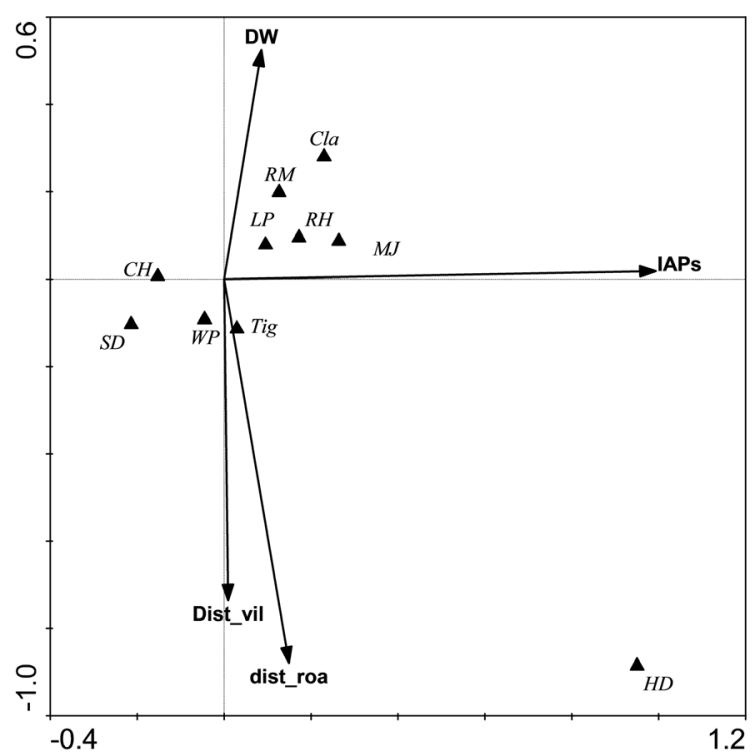

Fig. 5. CCA ordination diagram (biplot) showing species response to distance to road, village, water resource and invasive alien plant species (IAPs). Monte-Carlo permutation test of significance of all canonical axes: Trace $=0.167, \mathrm{~F}=$ $3.09, p=0.002$ (with 499 permutations). First two axes are displayed. The first axis accounts for $58.0 \%$ and the second axis $27.9 \%$ of the variability. 
disturbance factors that determine the distribution and nature of animals as the population density was more in the western region than the eastern region of BCF. Further, the relation between the large mammal species present and different parameters such as coverage of the natural habitats with invasive and alien plant species (IAPs), distance from the nearer water holes, distance from the village and roads found that most of the mammals avoid the area nearer to the settlements and roads. Chital, sambar, wild pig, hog deer, and tiger highly avoided the IAPs covered grasslands and other habitats (Fig. 5).

\section{Discussion}

\section{Distribution of mammals in habitat gradients}

Some species have a wide range of tolerant capacity as they can survive in a wide range of environmental conditions. Their distribution is not affected by the variations in the environment (MisHRA, 1982; TAMANG, 1982). The studies in the Chitwan National Park also showed that large mammals such as greater one-horned rhino, leopard, tiger, sambar, primates (rhesus monkey and Terai grey langur) are generalists and can survive in different habitats (Thapa, 2011; Bhattarai and Kindlmann, 2012a). Our study clearly showed the association of large mammals mostly with specific habitats such as hog deer, chital, wild pigs were closely associated with grassland likewise, northern red muntjac was found in grass patches scattered inside the forest. However, sambar deer was recorded in the dense forest of sal and riverine forests associated with grass patches likewise, primates used wide range of habitats. Most of the signs of tigers and leopards were found in grassland, tall grassland as the density of the prey was higher there. Study of Bhattarai and KindLMANN (2012a) found that the abundance of hog deer is closely associated with grassland found in the floodplain areas, while other ungulate species act like generalist species and associated with forest areas and grassland as our study. Chital are found in all types of habitat but they preferred grassland for grazing (WeGGe et al., 2009). Sambar deer was quite rare and it was relatively abundant in sal forests, as reported by DinERSTEIN (1979), THAPA (2011), and Pokharel and Storch (2016). Small patches of grassland scattered in dense forests (sal or riverine) with low vegetation are the preferred habitats for northern red muntjac. They used grass patches for grazing and dense forest for shelter (DinERSTEIN, 1979; WEGGE et al., 2009; ThaPA, 2011; BHATTARAI and KInDLMANN, 2012a). In our study, the wild pig was also recorded in open canopy area of grassland and moderately dense riverine forest. The grass patches inside the sal and mixed forest provided the most preferred habitat for wild pigs. Due to the presence of more soil invertebrates, wild pig used open areas nearer to the wetland for feeding and roosting. Likewise, they used sal and riverine forest for shelter (THURFJELL et al., 2009). Wild pigs are destructive in nature, hence, their presence lowers the presence of other herbivores (BARrios-Garcia and BALlARI, 2012; HorČIČKOVÁ et al.,
2019). Distribution of large mammals was affected by the forage availability in different habitats across the seasons. In the lowland Nepal, grasslands are usually dry during winter season. Therefore, large mammals tend to shift their food habit from grazer to browser and occupy the forest areas (LEHMKUHL, 1994).

The reproduction rate and population status of tiger and leopard are associated with the abundance of prey presence (GURUNG et al., 2006; KAfLEY et al., 2016). The presence of the tiger and leopard is correlated with the presence of ungulates and primates (WegGe and StoraAs, 2009). Our results showed that the abundance of signs of the tiger and leopard was higher in the open area of grassland and riverine forest where the abundance of chital, wild pig, hog deer and, northern red muntjac was high.

\section{Distribution of mammals in disturbance gradients}

Human disturbance indicators such as firewood collection, medicinal plant collection, livestock pressure, number of people inside the forest, tourist impacts directly or indirectly affect the distribution of mammals and other animals. BCF is surrounded by the large human settlements, Ratnanagar Municipality and Kalika Municipality in the eastern part and Bharatpur Metropolitan City in the western part. The local people depend upon the BCF for firewood, thatch grass and fodder plants. Previous researches also indicated the impacts of such type of disturbances that affect the distribution and abundance of mammals (HADDAD et al., 2015). The study on the livestock grazing pressure found a negative effect on the distribution of the mammals (Stephens et al., 2001; Bhattarai and Kindlmann, 2012b; Chillo et al., 2017; Soofi et al., 2018). In our study, we estimated the human disturbance status based on the number of signs of the disturbances present into five categories such as very low, low, moderate, high, or very high. We examined the effects of disturbance on the distribution of large mammals. The results indicated that most of the mammals were recorded in the very low and low disturbed areas while the rhesus monkeys were recorded in the highly disturbed areas nearer to the human settlements as they are synanthropic animals and familiar with people (Fig. 4). The previous results showed that human disturbances play a significant role in the occurrence probability of mammals. The presence of mammals was positively correlated with distance from settlements (LAIDLAW, 2000; OBEROSLER et al., 2017). The study of GAYNOR et al. (2018) found a strong effect of humans on daily patterns of wildlife activity. The effect may differ across continents, habitats, taxa, and human activities (Stephens et al., 2001; Bhattarai and Kindlmann, 2013; M'sOKA et al., 2017; OBEROSLER et al., 2017).

Muntjac is the smallest deer in our study area which commonly occurs nearer to the village but less sensitive to human disturbance (Mishra, 1982; BhATTARAI and KindLManN, 2013). However, this study recorded a large number of the muntjac in very low and low disturbance areas, hence very sensitive to human disturbance in BCF. Some of the mammal species such as rhesus monkeys and Terai grey langur were found in disturbed areas where predators usually avoided those areas (GILL et al., 2001), 
hence these species are able to coexist in the disturbed areas. However, other ungulates and signs of tiger and leopard were reported from the very low and low disturbed area, hence these mammals didn't follow this hypothesis.

Wildlife can't face a shortage of water in critical seasons (NAJAFI et al., 2019). Large mammals visit frequently to the water bodies, hence the sign and sightings of the large mammals are closer to the water sources (Cramer and Willig, 2002; BhatTARA and KINDLMANN, 2012a; ADHIKARI et al., 2019a) similar to our study. Similar results also found in the study of BHATTARAI and Kindlmann (2012a) and ThaPA (2011) in Chitwan National Park; WegGe et al. (2009) in Bardia National Park of Nepal. Hence, the presence of water resources inside the habitat is a key determinant of the distribution of mammals and other wildlife (BÁLDI, 2008; CROMSIGT et al., 2009; LAmichHANE et al., 2019b). During summer season, the temporary sources of water become dry, hence the natural and perpetual water resources played an important role to provide the drinking water to mammals. In the hot days, greater one-horned rhinos were usually observed wallowing in the water.

IAPs have been considered as major threats to protected areas, habitats, species, and native biodiversity in the world. They replaced the native plant species and destroy the habitat and foraging ground of herbivores (CLuSELLATrullas and Garcia, 2017). The highest densities of Mikania micrantha in the Chitwan National Park were found in the riverine forest, tall grass, and habitats nearer to the wetlands which is the preferred habitat of rhinoceros and other ungulates (MurPHy et al., 2013). Most of the species of mammals in our study avoided the area with high coverage of IAPs. Four types of invasive plants - Mikania micrantha, Chromolaena odorata, Lantana camara and Parthenium hysterophorus are very common and cover most of the grassland and forest in BCF. IAPs invasions change the habitats by outcompeting native plant species as IAPs have allelopathic characteristics (DumALISILE and SoMERs, 2017). So that follow up clearance of IAPs is necessary to restore habitats including ecosystem functioning. Hence, the main reason for the selection of different types of habitat types by ungulates was the presence of palatable vegetation, presence of water holes, beyond the human disturbance environments, presence of prey (for predators).

\section{Conclusions}

Habitat heterogeneity, disturbance, Invasive Alien Plant species (IAPs) cover and availability of water sources were the key factors for the distribution of the large mammals in the Barandabhar Corridor Forest (BCF). The ungulates were mostly recorded in the grassland and grass patches inside the forest. Maintaining spatial heterogeneity and controlling of invasive and alien species are the major challenges and should be the important goal of the management authorities of $\mathrm{BCF}$ for the conservation of tiger, leopard, and their prey species. Grassland management in BCF could significantly affect the abundance of ungulates. Human disturbances originated from people collecting thatched grass, firewood, and fodder plants including livestock grazing caused negative impacts on the distribution and diurnal activities of the large mammals such as rhinoceros, tiger, leopard, chital, and sambar in BCF. However, human disturbance was lower in Chitwan National Park (CNP) buffer zone part of BCF due to strict control by the park authorities. Community Forest has been managing grasslands and water sources but it is not sufficient to support the large mammals in the BCF. Hence, the concerned authority should plan to minimize the human, livestock pressure and cover of IAPs, and should take immediate action on scientific management of grasslands and water holes.

\section{Acknowledgements}

We are grateful to the Department of National Parks, and Wildlife Conservation (DNPWC), Nepal, Chitwan National Park and the Division Forest Office of Chitwan for providing the research permission. The equipment for field work was supported by Idea wild.

\section{References}

ACharya, K.P., 2018. Conservation conflict in Nepal: an examination of the pattern and ecological dimension of human-wildlife conflict and wildlife conservation. $\mathrm{PhD}$ thesis. Hamburg: Universität Hamburg. 92 p.

Adhikari, J.N., Bhattarai, B.P., ThaPA, T.B., 2019a. Determinants of distribution of large mammals in seti river basin, tanahun district of western Nepal. Journal of Institute of Science and Technology, 24 (1): 63-71. https:// doi.org/10.3126/jist.v24i1.24638

AdHiKari, J.N., BhatTARAi, B.P., ThaPA, T.B., 2019b. Factors affecting diversity and distribution of threatened birds in Chitwan National Park, Nepal. Journal of Threatened Taxa, 11 (5): 13511-13522. https://doi.org/10.11609/ jott.4137.11.5.13511-13522

BÁLDI, A., 2008. Habitat heterogeneity overrides the speciesarea relationship. Journal of Biogeography, 35 (4): 675681. https://doi.org/10.1111/j.1365-2699.2007.01825.x

Barrios-Garcia, M.N., Ballari, S.A., 2012. Impact of wild boar (Sus scrofa) in its introduced and native range: a review. Biological Invasions, 14 (11): 2283-2300. https://doi.org/10.1007/s10530-012-0229-6

Bartlett, L.J., Newbold, T., Purves, D.W., Tittensor, D.P., Harfoot, M.B., 2016. Synergistic impacts of habitat loss and fragmentation on model ecosystems. Proceedings of the Royal Society B: Biological Sciences, 283 (1839): 2016-1027. https://doi.org/10.1098/rspb.2016.1027

BhATTARAI, B.P., BASNET, K., 2004. Assessment of crop damage by wild ungulates in the eastern side of Barandabhar Corridor Forest, Chitwan. In Fourth National Conference on Science and Technology, March 23-26, 2004. Book of proceedings. Khumaltar, Lalitpur, Nepal: Nepal Academy of Science and Technology, p. 1976-1980.

Bhattarai, B.P., KindlmanN, P., 2012a. Habitat heterogeneity 
as the key determinant of the abundance and habitat preference of prey species of tiger in the Chitwan National Park, Nepal. Acta Theriologica, 57 (1): 89-97. https:/doi. org/10.1007/s13364-011-0047-8

BhatTARAI, B.P., KindLMAnN, P., 2012b. Impact of livestock grazing on the vegetation and wild ungulates in the Barandabhar Corridor Forest, Nepal. In KindlmanN, P. (ed.). Himalayan biodiversity in the changing world. Dordrecht: Springer, p. 157-175. https://doi. org/10.1007/978-94-007-1802-9_7

Bhattarai, B.P., Kindlmann, P., 2013. Effect of human disturbance on the prey of tiger in the Chitwan National Park - implications for park management. Journal of Environmental Management, 131: 343-350. https:/doi. org/10.1016/j.jenvman.2013.10.005

Bhattarai, B.P., Kindlmann, P., 2018. Factors affecting population composition and social organization of wild ungulates in the Chitwan National Park, Nepal. Journal of Institute of Science and Technology, 22 (2): 156-167. https://doi.org/ 10.3126/jist.v22i2.19608

Buckland, S.T., Rexstad, E.A., Marques, T.A., Oedekoven, C.S., 2015. Distance sampling: methods and applications. Methods in statistical ecology. Berlin: Springer. https:/ doi.org/10.1007/978-3-319-19219-2

Chillo, V., Ojeda, R.A., Capmourteres, V., Anand, M., 2017. Functional diversity loss with increasing livestock grazing intensity in drylands: the mechanisms and their consequences depend on the taxa. Journal of Applied Ecology, 54 (3): 986-996. https:/doi.org/10.1111/13652664.12775

Clusella-Trullas, S., Garcia, R.A., 2017. Impacts of invasive plants on animal diversity in South Africa: a synthesis. Bothalia-African Biodiversity Conservation, 47 (2): 1-12. https://doi.org/10.4102/abc.v47i2.2166

Cramer, M.J., Willig, M.R., 2002. Habitat heterogeneity, habitat associations, and rodent species diversity in a sand-shinnery-oak landscape. Journal of Mammalogy, 83 (3): 743-753. https://doi.org/10.1644/15451542(2002)083<0743:HHHAAR >2.0.CO;2

Cromsigt, J.P.G.M., Prins, H.H.T., OlfF, H., 2009. Habitat heterogeneity as a driver of ungulate diversity and distribution patterns: interaction of body mass and digestive strategy. Diversity and Distributions, 15 (3): 513-522. https://doi.org/10.1111/j.1472-4642.2008.00554.x

Dinerstein, E., 1979. An ecological survey of the Royal Karnali-Bardia wildlife reserve, Nepal. Part II: Habitat/ animal interactions. Biological Conservation, 16 (4): 265-300. https://doi.org/10.1016/0006-3207(79)90055-7

Dumalisile, L., Somers, M.J., 2017. The effects of an invasive alien plant (Chromolaena odorata) on large African mammals. Nature Conservation Research, 2 (4):102-108. https://doi.org/ 10.24189/ncr.2017.048

Erb, P.L., MCshea, W.J., GuRALnick, R.P., 2012. Anthropogenic influences on macro-level mammal occupancy in the Appalachian Trail corridor. PLOS One, 7 (8): e42574. https://doi.org/10.1371/journal. pone. 0042574

Gaynor, K.M., Hojnowski, C.E., Carter, N.H., Brashares, J.S., 2018. The influence of human disturbance on wildlife nocturnality. Science, 360 (6394): 1232-1235. https://doi. org/10.1126/science.aar7121
Gill, J.A., Norris, K., Sutherland, W., 2001. Why behavioural responses may not reflect the population consequences of human disturbance. Biological Conservation, 97 (2): 265-268. https://doi.org/10.1016/ S0006-3207(00)00002-1

Gurung, B., Smith, J.D., Mcdougal, C., Karki, J., 2006. Tiger human conflicts: investigating ecological and sociological issues of tiger conservation in the buffer zone of Chitwan National Park, Nepal. Final report. Submitted to WWF-Nepal Program, Kathmandu, Nepal. 61 p. [cit. 2020-09-02]. http://www.indiaenvironmentportal.org.in/ files/Tiger\%20human\%20conflicts.pdf

Haddad, N.M., Brudvig, L.A., Clobert, J., Davies, K.F., Gonzalez, A., Holt, R.D., Sexton, J.O., Austin, M.P., Collins, C.D., Cook, W.M., Damschen, E.I., Ewers, R.M., Foster, B.L., Jenkins, C.N., King, A.J., Laurance, W.F., Levey, D.J., Margules, C.R., Melbourne, B.A., Nicholls, A.O., Orrock, J.L., Song, D., Townshend, J.R. 2015. Habitat fragmentation and its lasting impact on Earth's ecosystems. Applied Ecology, 1 (2): e1500052. https://doi.org/10.1126/sciadv.1500052

HorČıČKová, E., BRŮNA, J., VoJTA, J., 2019. Wild boar (Sus scrofa) increases species diversity of semidry grassland: field experiment with simulated soil disturbances. Ecology and Evolution, 9 (5): 2765-2774. https://oi. org/10.1002/ece 3.4950

ICIMOD, 2013. Land cover of Nepal 2010. The International Centre for Integrated Mountain Development (ICIMOD). [online]. [cit. 2020-07-29]. https://rds.icimod.org/Home/ DataDetail metadataId $=9224$

Kafley, H., Gomprer, M.E., Sharma, M., Lamichane, B.R., Maharjan, R., 2016. Tigers (Panthera tigris) respond to fine spatial-scale habitat factors: occupancy-based habitat association of tigers in Chitwan National Park, Nepal. Wildlife Research, 43 (5): 398-410. https://doi. org/10.1071/WR16012

LAIDLAW, R.K., 2000. Effects of habitat disturbance and protected areas on mammals of Peninsular Malaysia. Conservation Biology, 14 (6): 1639-1648. https://doi.org/ 10.1111/j.1523-1739.2000.99073.x

Lamichhane, B.R., Leirs, H., Persoon, G.A., Subedi, N., Dhakal, M., Oli, B.N., Reynaert, S., Sluydts, V., PoKheral, C.P., Poudyal, L.P., 2019a. Factors associated with co-occurrence of large carnivores in a humandominated landscape. Biodiversity Conservation, 28 (6): 1473-1491. https://doi.org/10.1007/s10531-019-01737-4

Lamichinane, B.R., Persoon, G.A., Leirs, H., Poudel, S., Subedi, N., Pokheral, C.P., Bhattarai, S., Gotame, P., Mishra, R., De Iongh, H.H., 2019b. Contribution of buffer zone programs to reduce human-wildlife impacts: the case of the Chitwan National Park, Nepal. Human Ecology, 47 (1): 95-110. https://doi.org/10.1007/s10745019-0054-y

LehmKunL J.F., 1994. A classification of subtropical riverine grasslandand forest in Chitwan National Park, Nepal. Vegetatio, 111: 29-43. https://doi.org/ 10.1007/ BF00045575

M'soka, J., Creel, S., Becker, M.S., Murdoch, J.D., 2017. Ecological and anthropogenic effects on the density of migratory and resident ungulates in a human-inhabited 
protected area. African Journal of Ecology, 55 (4): 618631. https://doi.org/10.1111/aje.12398

MacarthuR, R.H., Macarthur, J.W., 1961. On bird species diversity. Ecology, 42 (3): 594-598. https://doi. org/10.2307/1932254

Macfaden, S.W., CAPEN, D.E., 2002. Avian habitat relationships at multiple scales in a New England forest. Forest Science, 48 (2): 243-253. https://doi.org/10.1093/ forestscience $/ 48.2 .243$

Mishra, H.R., 1982. The ecology and behaviour of chital (Axis axis) in the Royal Chitwan National Park, Nepal: with comparative studies of hog deer (Axis porcinus), sambar (Cervus unicolor) and barking deer (Muntiacus muntjak). $\mathrm{PhD}$ thesis. Edinburgh: University of Edinburgh.

Murphy, S.T., Subedi, N., Jnawali, S.R., LamichHane, B.R., UpadhyaY, G.P., Kock, R., Amin, R., 2013. Invasive mikania in Chitwan National Park, Nepal: the threat to the greater one-horned rhinoceros Rhinoceros unicornis and factors driving the invasion. Oryx, 47 (3): 361-368. https://doi.org/10.1017/S003060531200124X

Najafi, J., Farashi, A., Zanoosi, A.P., Yadreh, R., 2019. Water resource selection of large mammals for water resources planning. European Journal of Wildlife Research, 65 (6): art. no. 82. https://doi.org/10.1007/ s10344-019-1321-3

Oberosler, V., Groff, C., Iemma, A., Pedrini, P., Rovero, F., 2017. The influence of human disturbance on occupancy and activity patterns of mammals in the Italian Alps from systematic camera trapping. Mammalian Biology, 87 (1): 50-61. https://doi.org/10.1016/j.mambio.2017.05.005

Oberosler, V., Tenan, S., Zipkin, E.F., Rovero, F., 2020. When parks work: effect of anthropogenic disturbance on occupancy of tropical forest mammals. Ecology and Evolution, 10 (9): 3881-3894. https://doi.org/10.1002/ ece3.6048

PoKharel, K.P., StORCH, I., 2016. Habitat niche relationships within an assemblage of ungulates in Bardia National Park, Nepal. Acta Oecologica, 70: 29-36. https://doi. org/10.1016/j.actao.2015.11.004

Ravenelle, J., Nyhus, P., 2017. Global patterns and trends in human-wildlife conflict compensation. Conservation biology, 31 (6): 1247-1256. https://doi.org/ 10.1111/ cobi. 12948

Rodrigues, A.S., Pilgrim, J.D., Lamoreux, J.F., Hoffmann, M., Brooks, T.M., 2006. The value of the IUCN Red List for conservation. Trends in Ecology and Evolution, 21 (2): 71-76. https://doi.org/10.1016/j.tree.2005.10.010

Saisamorn, A., Duengkae, P., Pattanavibool, A., Duangchantrasiri, S., Simcharoen, A., Smith, J.L.D., 2019. Spatial and temporal analysis of leopards (Panthera pardus), their prey and tigers (Panthera tigris) in Huai Kha Khaeng Wildlife Sanctuary, Thailand. Folia Oecologica, 46 (2): 73-82. https://doi.org/10.2478/foecol-2019-0010

SCHALLER, G., 1967. The deer and the tiger: a study of wildlife in India. London: University of Chicago Press. 370 p.

Silveira, L., JaComo, A.T., Diniz-FiLho, J.A.F., 2003. Camera trap, line transect census and track surveys: a comparative evaluation. Biological Conservation, 114 (3): 351-355. https://doi:.org/10.1016/S0006-3207(03)00063-6

Soofi, M., Ghoddousi, A., Zeppenfeld, T., Shokri, S., Soufi, M., Jafari, A., Ahmadpour, M., Qashqaei, A.T., EgLI, L., Ghadirian, T., 2018. Livestock grazing in protected areas and its effects on large mammals in the Hyrcanian forest, Iran. Biological Conservation, 217: 377-382. https://doi.org/10.1016/j.biocon.2017.11.020

Stephens, P.A., D'sa, C.A., Sillero-Zubiri, C., LeaderWilliams, N., 2001. Impact of livestock and settlement on the large mammalian wildlife of Bale Mountains National Park, southern Ethiopia. Biological Conservation, 100 (3): 307-322. https://doi.org/10.1016/S0006-3207(01)000350

Tamang, K.M., 1982. The status of the tiger (Panthera tigris) and its impact on principal prey populations in Royal Chitwan National Park, Nepal. PhD thesis. East Lansing, MI, USA: Michigan State University. 123 p.

Ter Braak, C., Šmilauer, P., 2009. Canoco for Windows $V$ 4.56. Wageningen, the Netherlands: Biometris quantitative methods in the life and earth sciences, Plant Research International, Wageningen University and Research Centre.

Tews, J., Brose, U., Grimm, V., Tielbörger, K., Wichmann, M.C., Schwager, M., Jeltsch, F., 2004. Animal species diversity driven by habitat heterogeneity/diversity: the importance of keystone structures. Journal of Biogeography, 31 (1): 79-92. https://doi.org/10.1046/ j.0305-0270.2003.00994.x

THAPA, T.B., 2011. Habitat suitability evaluation for Leopard (Panthera pardus) using remote sensing and GIS in and around Chitwan National Park, Nepal. PhD thesis. Rajkot: Saurashtra University. 228 p.

Thurfjell, H., Ball, J.P., Åhlén, P., Kornacher, P., DettKi, H., SJöBerg, K., 2009. Habitat use and spatial patterns of wild boar Sus scrofa (L.): agricultural fields and edges. European Journal of Wildlife Research, 55 (5): 517-523. https://doi.org/10.1007/s10344-009-0268-1

Wang, G., HobBs, N.T., Boone, R.B., Illius, A.W., Gordon, I.J., Gross, J.E., Hamlin, K.L., 2006. Spatial and temporal variability modify density dependence in populations of large herbivores. Ecology, 87 (1): 95-102. https://doi. org/10.1890/05-0355

Wegge, P., Odden, M., Pokharel, C.P., Storaas, T., 2009. Predator-prey relationships and responses of ungulates and their predators to the establishment of protected areas: a case study of tigers, leopards and their prey in Bardia National Park, Nepal. Biological Conservation, 142 (1): 189-202. https://doi.org/10.1016/j.biocon.2008.10.020

Wegge, StoraAs, T., 2009. Sampling tiger ungulate prey by the distance method: lessons learned in Bardia National Park, Nepal. Animal Conservation, 12 (1): 78-84. https:// doi.org/10.1111/j.1469-1795.2008.00230.x

Received September 21, 2020 Accepted December 5, 2020 